\title{
Methodology adaptation and development to assess salt content dynamics and salt balance of soils under secondary salinization
}

\author{
Arzu Rivera Garcia ${ }^{1,2}$ - Géza Tuba ${ }^{2}$ - Györgyi Kovács ${ }^{2}$ - Lúcia Sinka ${ }^{1,2}$ - József Zsembeli ${ }^{2}$ \\ ${ }^{1}$ Faculty of Agricultural and Food Sciences and Environmental Management, University of Debrecen, 4032 Debrecen, Böszörményi út 138., \\ Hungary \\ ${ }^{2}$ Karcag Research Institute, IAREF, University of Debrecen, 5300 Karcag, Kisújszállási út 166. Hungary \\ zsembeli@agr.unideb.hu
}

\begin{abstract}
SUMMARY
The effect of irrigation with saline water (above $500 \mathrm{mg} \mathrm{L}^{-1}$ ) is considered a problem of small-scale farmers growing vegetable crops with high water demand in the hobby gardens characteristic of the Hungarian Great Plain. In order to simulate the circumstances of such hobby garden, we set up an experiment including five simple drainage lysimeters irrigated with saline water in the Research Institute of Karcag IAREF UD in 2019. We regularly measured the electric conductivity (EC) of the soil referring to its salt content and the soil moisture content with mobile sensors. Before and after the irrigation season, soil samples from the upper soil layer (0-0.6 $\mathrm{m})$ were taken for laboratory analysis and the soil salt balance $(S B)$ was calculated. The actual salt balance $\left(S B_{\text {act }}\right)$ was calculated of the upper soil layer $(0-0.6 \mathrm{~m})$ based on the salt content of the obtained soil samples. The theoretical salt balance $\left(S B_{t}\right)$ was calculated by the total soluble salt content of the irrigation water and leachates. During the irrigation season, we experienced fluctuating EC in the topsoil in close correlation with the soil moisture content. Based on the performed in-situ EC measurements, salts were leached from the upper soil layer resulting in a negative $S B$. Combining $S B_{\text {act }}$ and $S B_{\text {th }}$ of the soil columns of the lysimeters, we estimated the SB of the deeper $(0.6-1.0 \mathrm{~m})$ soil layer. We quantified $12 \%$ increase of the initial salt mass due to accumulation. We consider this methodology to be suitable for deeper understanding secondary salinization, which can contribute to mitigating its harmful effect. By repeating our measurements, we expect similar results proving that saline irrigation waters gained from the aquifers through drilled wells in Karcag are potentially suitable for irrigation if proper irrigation and soil management are applied.
\end{abstract}

Keywords: secondary salinization; salt mass balance; lysimeters; leaching; irrigation

\section{INTRODUCTION}

Agriculture is the dominant economic activity for many people and regions around the world. Regarding to small scale farming during the last decades the demographic changes and the improved of the infrastructure has converted the agriculture in to a profitable enterprise (Ali and Kapoor, 2008). In fact, the scarcity and degradation of land is more endangered in semi-arid areas due to climate change and extreme conditions in the weather. Salinization is one of the problems of arable lands and nowadays in the world exist $30 \%$ loss of land, with some estimates as high as $50 \%$ by 2050 (Wang et al., 2003). The water scarcity and some other problems such as water-logging, salinization, and soil and water quality degradation are a threat to the future of irrigated agriculture. Half of all irrigated soils is affected by soil salinity. In semiarid region the major soil degradation threats is the mismanaged irrigation, affecting over $10 \%$ of the total irrigated land (Lambert and Shaiti, 2002). New incentives and policies for ensuring the sustainability of agriculture and ecosystem services will be crucial if we are into the commitment to satisfy the demands of yields without compromising environmental integrity or public health (Tilman et al., 2002).

Nowadays, low scale farming has different problems, where the interactions between agriculture and the environment can be especially unequal, as they are determined by the scarcity of land or resources (Fida and Pnuma, 2013). These agricultural heritages are covering some 5 million hectares and providing a series of ecological and cultural services to people, such as the preservation of traditional forms of farming knowledge, local crop and animal varieties and sociocultural organization (Altieri and Koohafkan, 2008). Small-scale farmers are considered the most vulnerable group to climate change due to the pressure of consuming goods and services that ecosystem provides; the low capacity to adapt to climate change; dependence on rain season; location of the small holders which are exposed to a variety of climate hazards and the negative impacts on productivity (Donatti et al., 2019).

The small-scale hobby gardens around the town of Karcag, Hungary have been utilized for horticultural activities for more than 300 years, so it is a long tradition of the citizens to grow vegetables and fruits there, mainly for their own consumption but also for the local market. The soils in these hobby gardens have an excess of salts because the irrigation water is coming from drilled wells extracting saline subsurface waters (Zsembeli et al., 2011). In previous studies, it was proven that the underground waters in Karcag are not suitable for irrigation (Zsembeli et al., 2013) The soils irrigated with aquifer waters usually contain adsorbed sodium as well adsorbed calcium and magnesium, which has an effect to the soil called secondary salinization. Irrigation can control the salt balance in the root zone by adjusting the irrigation rate and the salinity of water used for irrigation. However, the amount of salts leaching from the root zone will impact on the salt balance (Bower, 1959). Management of saline water for irrigation is often based on application of excess water, designed to maintain minimum root zone salinity and thus minimize salinity caused yield 
water consumption and bring satisfactory yields (BenGal et al., 2008). Another measure to manage salts is soil conditioning in order to improve the status of salt affected or potentially salt affected soils susceptible for secondary salinization (Zsembeli et al., 2019b; Rivera et al., 2020; Kovács, 2015). The main goal is to stop the effect of soil salinity and prevent stress in the plants like osmotic imbalance, reduced water uptake and transpiration, reduced yields (Burt and Isbell, 2005).

The soil salt balance is the relationship between the mass of salt entering and leaving an area of land. Generally, a favourable salt balance (mass out $\geq$ mass in) is considered necessary for sustainable irrigated agriculture (Thayalakumaran et al., 2007). Therefore, irrigated agriculture depends on protecting land and water resources from salinity and protecting the rootzone against salinity (Sharma, 1999). A system with increasing salt storage (net accumulation of salts) is considered to have a risk of salinization to land and water resources. The salt balance is applied at the root zone as an indicator of productivity, leaching, drainage, irrigation and salinization (Rhoades et al., 1997). Salt composition of the soil solution influences the composition of cation exchange and affects on soil structure and hydraulic properties. Therefore, the best strategy is to flush and maintain the salt solution below the root zone, but in Karcag, irrigation water is a limiting factor due to its poor quality. In order to prevent salinization, it is necessary to schedule the irrigation by selecting the amount and timing of irrigation to minimize salt accumulation (Sinka et al., 2019).

The principal aim of our secondary salinization related research is to understand the dynamics of salt balance in salt affected soils to adapt mitigation techniques for the long-term sustainability of soil protective crop production and horticulture. As a part of this research, the quantification of soil salt content dynamics and salt balance were the goals of this study by adapting and developing the recent methods to our specific agri-ecological conditions studied in a lysimeter environment.

\section{MATERIALS AND METHODS}

In order to describe the leaching process and determine the salt mass balance of the soil, we set up an experiment in 5 simple drainage lysimeters (giving 5 replications) irrigated with saline water in the Lysimeter Station of the Research Institute of Karcag IAREF University of Debrecen (RIK). The lysimeters contain a heavy textured meadow chernozem soil salty in the deeper layers. This is one of the three typical soil types of the region, and it is especially characteristic in the hobby gardens located in the western part of Karcag. We simulated the circumstances of the production in these gardens; therefore, we created the excess of salts in the A-horizon of the soil by means of irrigation with saline well water (coming from the top aquifer) in each lysimeter. The salt content of the irrigation water we used was around $10,000 \mathrm{mg} \mathrm{L}^{-1}$, which is the double of the upper threshold determined in the regulation as the maximum salt content of waters allowed to use for irrigation in Hungary. In our study carried out in 2019, we applied the irrigation protocol and the most suitable frequency according to a preliminary experiment of Sinka et al. (2019). All the lysimeters were irrigated with the same weekly amount of water (16 litres per week). We chose chilli pepper (Capsicum annuum L.) as the indicator crop, because due to its shallow root system, it extracts $70-80 \%$ of its water demand from the top $0.3 \mathrm{~m}$ soil layer. It is known to be sensitive to salt accumulation $\left(1.5 \mathrm{mS} \mathrm{cm}^{-1}\right)$ and has high water demand (needs much irrigation water during its vegetation period). Only N-P-K fertilization was applied according to the demand of the indicator crop (Ben-Gal et al., 2008; Barrios et al., 2007).

We irrigated the chilli plants with the same amount of salty water in each lysimeter and determined how much salt was added through irrigation taking the total amount of irrigation water and its regularly measured salt concentration into account. During the irrigation season (May-October 2019), in situ measurements were carried out two times a week. The electric conductivity (EC) of the soil referring to its salt content was measured with an UMP-1 mobile probe, while soil moisture content with an SMT 100 sensor, both produced by Umwelt-Geräte-Technik GmbH. In order to determine the correlation between these two variables, Pearson correlation coefficient was calculated by means of Microsoft Excel 2010 software. We also regularly recorded the amount of precipitation at the Meteorological Station of Karcag and determined the amount and quality leachates outflowing from the lysimeters when the soil was saturated over its field capacity.

Lysimeters are effective, versatile tools and very suitable tools for the precise quantification of the processes determining the water- and salt balance of the soil (Zsembeli et al., 2019a) as the elements of the soil water balance and their chemical compositions can be precisely determined. The theoretical salt balance (SBTH) of the soil columns of the lysimeters was calculated taking the total salt content of the irrigation water (input in a lysimeter system) and of the leachates (output in a lysimeter system) into account. The salt content of natural precipitation (input) was considered zero in this study, and no other salt inputs and outputs were taking place in the salt regime of the lysimeters. Wilcox's (1963) equations were adapted to calculate the relevant amount of the total dissolved salt mass (SM) of the irrigation water (Eq. 1) and the leachate (Eq. 2) from which SBTH was derived (Eq. 3).

$$
\mathrm{SM}_{\text {Irr }}=\left(\mathrm{V}_{\mathrm{IRR}} * \mathrm{C}_{\mathrm{Irr}}\right)
$$

where $\mathrm{SM}_{\text {Irr }}$ is the total dissolved salt mass $(\mathrm{g}), \mathrm{V}_{\text {Irr }}$ is the volume $(\mathrm{L})$, and $\mathrm{C}_{\mathrm{Irr}}$ is the salt concentration $\left(\mathrm{g} \mathrm{L}^{-1}\right)$ in the irrigation water, respectively.

$$
\mathrm{SM}_{\mathrm{Lch}}=\left(\mathrm{V}_{\mathrm{Lch}} * \mathrm{C}_{\mathrm{Lch}}\right)
$$

where $\mathrm{SM}_{\mathrm{Lch}}$ is the total dissolved salt mass $(\mathrm{g}), \mathrm{V}_{\mathrm{Lch}}$ is the volume $(\mathrm{L})$, and $\mathrm{C}_{\mathrm{Lch}}$ is the salt concentration $\left(\mathrm{g} \mathrm{l}^{-\mathrm{L}}\right)$ in the leachate, respectively. 


$$
\mathrm{SB}_{\mathrm{TH}}=\mathrm{SM}_{\mathrm{Irr}}-\mathrm{SM}_{\mathrm{Lch}}
$$

where $\mathrm{SB}_{\mathrm{TH}}$ is the theoretical salt balance.

If $\mathrm{SB}_{\mathrm{TH}}$ is equal to zero, neither accumulation nor leaching is taking place in the investigated soil layer.

We used this method, because it is the simplest and the most obvious procedure for a simple drainage lysimeter system as it is based on measured values of inputs and outputs. However, this methodology can also be used to calculate the leaching requirement, which means the fraction of the irrigation water that must be percolated out of the root zone to prevent high salinity exceeding a specified level (Hillel, 2005).

Before the irrigation season, we took soil samples from the soil layers of $0-0.2,0.2-0.4$, and $0.4-0.6 \mathrm{~m}$, respectively. The samples were analysed in the Central Laboratory of RIK, where the actual conductivity saturation extract $\left(\mathrm{EC}_{\mathrm{E}}\right)$ was measured by making a saturated paste of soil, adding deionized water to it, extracting the water, and then measuring the $\mathrm{EC}$ of the extracted solution with a potentiometer. From $\mathrm{EC}_{\mathrm{E}}$, the total soluble salt concentration (TSC in $\mathrm{w} / \mathrm{w} \%$ ) was determined according to the Hungarian standard MSZ08 0206/2-78. The sampling and analysis were repeated similarly after the irrigation season.

On the base of the TSC of the soil samples taken before and after the irrigation season, the actual salt balance $\left(\mathrm{SB}_{\mathrm{ACT}}\right)$ of the upper three $(0-0.2,0.2-0.4,0$ $0.4-0.6 \mathrm{~m})$ soil layers was calculated. First, we calculated the volume $\left(\mathrm{V}\right.$ in $\left.\mathrm{m}^{3}\right)$ of a specific $(0.2 \mathrm{~m}$ thick) soil layer of the lysimeters of $0.8 \mathrm{~m}^{2}$ soil surface each getting $0.16 \mathrm{~m}^{3}$ as $\mathrm{V}$. Then the mass of a $0.2 \mathrm{~m}$ thick soil layer $\left(\mathrm{m}_{\text {soil }}\right)$ can be calculated from $\mathrm{V}$ and the relevant soil bulk density $\left(\rho_{\mathrm{b}}\right.$ in $\mathrm{Mg} \mathrm{m}^{3}$ ) as their product (Eq. 4).

$$
\mathrm{m}_{\text {soil }}=\mathrm{V} * \rho_{\mathrm{b}}
$$

Knowing $\mathrm{m}_{\text {soil }}$ (in $\mathrm{g}$ ) and TSC (in w/w\%) of a soil layer, its total salt mass (TSM in g) can be calculated according to Eq. 5 .

$$
\mathrm{TSM}=\mathrm{m}_{\text {soil }} * \mathrm{TSC} / 100
$$

To quantify $\mathrm{SB}_{\mathrm{ACT}}$, it can be derived from TSM values determined before $\left(\mathrm{TSM}_{\mathrm{ini}}\right)$ and after $\left(\mathrm{TSM}_{\text {final }}\right)$ the irrigation season (Eq. 6).

$$
\mathrm{SB}_{\mathrm{ACT}}=\mathrm{TSM}_{\mathrm{ini}}-\mathrm{TSM}_{\mathrm{final}}
$$

\section{RESULTS AND DISCUSSION}

\section{Salt content dynamics}

The dynamics of the EC and the moisture content in the upper soil layer is essential to understand the salinization process. The results of the regularly measured soil EC and moisture content in the $0-0.1 \mathrm{~m}$ soil layer are shown in Figure 1. It is obvious that the soil moisture content was between the desired 10 and $20 \mathrm{v} / \mathrm{v} \%$ most of the time, but sometimes under that range. The soil EC was found to be dependent on the soil moisture content due to the high salt content of the irrigation water. The Pearson correlation test proved the strong association between these two continuous variables $(r=0.774)$. In fact, secondary salinization was taking place proving that irrigation water was the only source of salt causing higher EC. In the irrigation season, the salts from the irrigation water temporarily accumulate on the surface of the soil particles due to the electrical charges. When the soil is dry the adsorbed ions are bounded firmly to the soil particles, but these adsorbed ions can interchange freely with other soluble cations like $\mathrm{Na}^{+}$. As the proportion of sodium increases, the soil tends to become dispersed and impermeable to water and air, also the ratio in $\mathrm{K}^{+} / \mathrm{Na}^{+}$change creating a deficient nutrition to the roots (Revee and Fireman, 1967; Rangjian et al., 2018).

Figure 1. Dynamics of soil EC and moisture content in the $\mathbf{0}-\mathbf{1 0} \mathbf{c m}$ soil layer

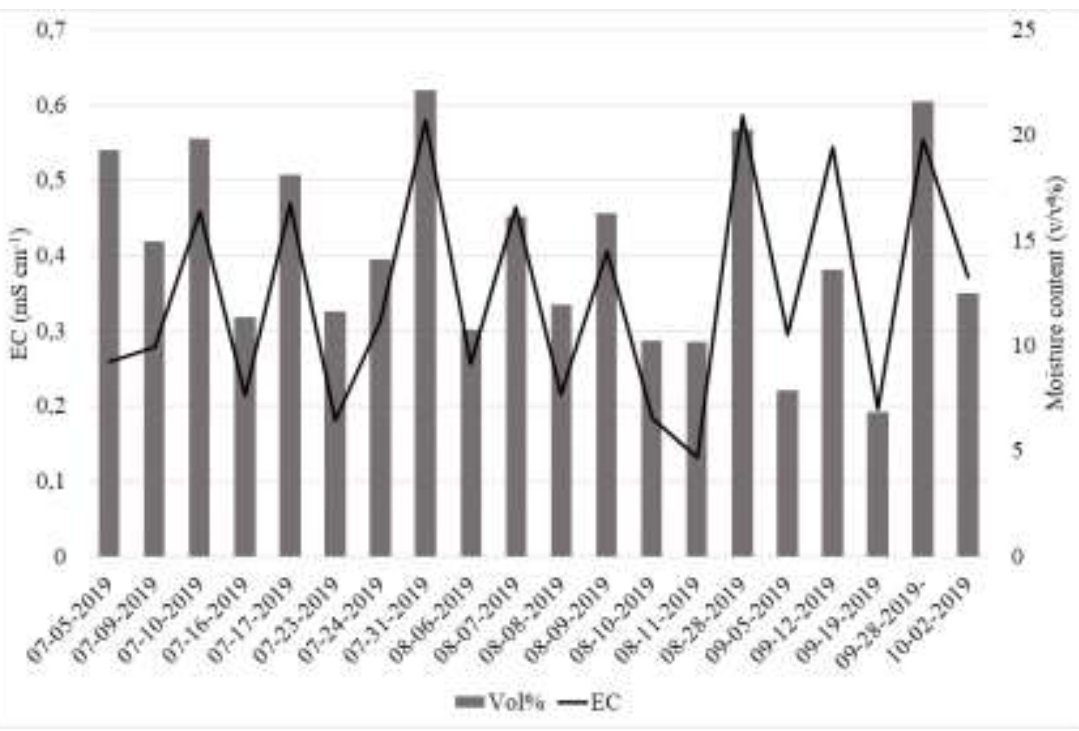


Salt balance and leaching are two basic concepts relating to salinity control that have useful applications to water management in agriculture. The salts move and accumulate in soils largely as a result of movement of water. Measurements of soil water flux and salt movement in soil are difficult to appreciate due to the physical and chemical complexity of most natural soils (Bergstrom, 1990). To calculate the $\mathrm{SB}_{\mathrm{TH}}$ for our lysimeters, we had to know the total salt input from the irrigation water and the total output of the soil of the lysimeters (leachate). $V_{\text {Irr }}$ was the same for each lysimeter, but we expected some differences in $\mathrm{V}_{\mathrm{Lch}}$ among the lysimeters due to some heterogeneity in the soil structure. We also assumed some changes in $\mathrm{C}_{\text {Irr }}$ and $\mathrm{C}_{\mathrm{Lch}}$. during the investigated period. Therefore, we regularly measured the salinity $\left(\mathrm{mg} \mathrm{L}^{-1}\right)$ of the irrigation water and the leachates to determine the dynamics of these parameters (Figure 2). The average salt content of the leachate was more concentrated than the irrigation water. Each horizon of the soil columns retained water and salts for a while, and there were slight differences among the lysimeters as replications in the duration of absorbing and retaining the water. For example, during the investigated season of 2019, the first leachate appeared 4 weeks after the irrigation was started, while in some lysimeters a few days later. Likewise, there were some differences in $\mathrm{V}_{\mathrm{Lch}}$ and $\mathrm{C}_{\mathrm{Lch}}$ among the lysimeters as well, $\mathrm{C}_{\mathrm{Lch}}$ varied in the range of 4,000-8,000 $\mathrm{mg} \mathrm{L}^{-1}$.

Figure 2. Dynamics of the salt content of the irrigation (input) and leachate (output) waters in the lysimeter experiment in 2019

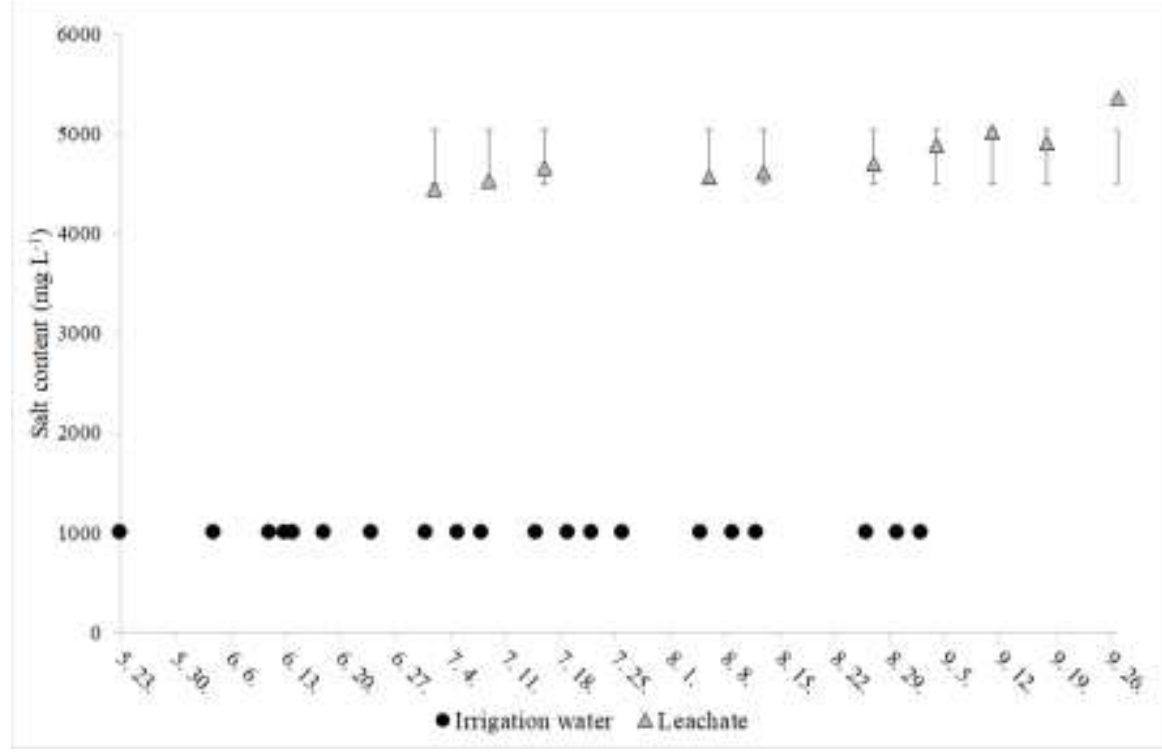

We determined the monthly $\mathrm{SM}_{\text {Irr }}$ and $\mathrm{SM}_{\mathrm{Lch}}$ values for the four months of the irrigation season in 2019, and for the rest of the leaching season (2019-2020), when no salt input just output occurred (Figure 3). We consider the leaching season as the period between the first and last appearance of leachate. The leachate season is very informative in terms of the efficiency of irrigation and the soil moisture profile. The length of the overlap between the irrigation and leachate seasons can indicate if the intensity of irrigation and the hydraulic conductivity of the soil is in harmony or not. The length of the leachate season after the end of the irrigation season is also important showing if there is a chance for the natural precipitation to leach out the harmful salts from the root zone providing good soil status for the next year's crop. The date of the last appearance of leachate (end of the leaching season) is expected to be variable in accordance with the climate change and the increasing frequency of hydrological extremes. The climate conditions have major influence on the rate of processes salt balance. Annual rainfall and weather affect the salinization and desalinisation cycles. For example, rainfall or flooding may leach sufficient salt to achieve a root-zone salt balance under drainage conditions can enhance salt reduction in the root-zone. Furthermore, by means of irrigation, salty water can percolate into the subsoil and the level of groundwater can rise near the surface (Martínez, 2002).

The monthly values of the salt mass inputs and outputs provide information not only on the dynamics, but on the monthly $\mathrm{SB}_{\mathrm{TH}}$ of the soil too (Figure 3). During June and July, positive $\mathrm{SB}_{\mathrm{TH}}$ was assumed, because there was not significant amount of leachate. In August, the lower amount irrigation and the more considerable amounts of leachate, which removed plenty of salts from the upper layer, resulted in negative $\mathrm{SB}_{\mathrm{TH}}$. After the irrigation season, no salt input but extensive leaching was characteristic due to the natural precipitation in the rest of the year. The dynamics of the salt input and output is dependent on the irrigation water or salt input, but annual weather patterns affect salinization and desalinisation cycles in the root zone (Thayalakumaran et al., 2007). Naturally, the rain and melted snow intensify salt outlet during the rest of the 
leaching season resulting in negative $\mathrm{SB}_{\mathrm{TH}}$. In our case, natural precipitation of $389.3 \mathrm{~mm}(65.5 \mathrm{~mm}$ in June, $59.5 \mathrm{~mm}$ in July, $14.6 \mathrm{~mm}$ in August, $40.6 \mathrm{~mm}$ in September, $8.4 \mathrm{~mm}$ in October, $72.2 \mathrm{~mm}$ in November, $34.1 \mathrm{~mm}$ in December, $19.8 \mathrm{~mm}$ in January, $40.2 \mathrm{~mm}$ in February, $34.4 \mathrm{~mm}$ in March, respectively) contributed to increase the actual soil moisture content of the lysimeters and to the $72.8 \mathrm{~mm}$ total average amount of leachate. As an average, $13.3 \%$ of the total water input (precipitation + irrigation) was outlet from the lysimeter system by leaching. This ratio also characterises each specific crop year.

Figure 3. Monthly dynamics of salt mass inputs and outputs of the soil columns of the lysimeters during the irrigation and leaching seasons of 2019-2020

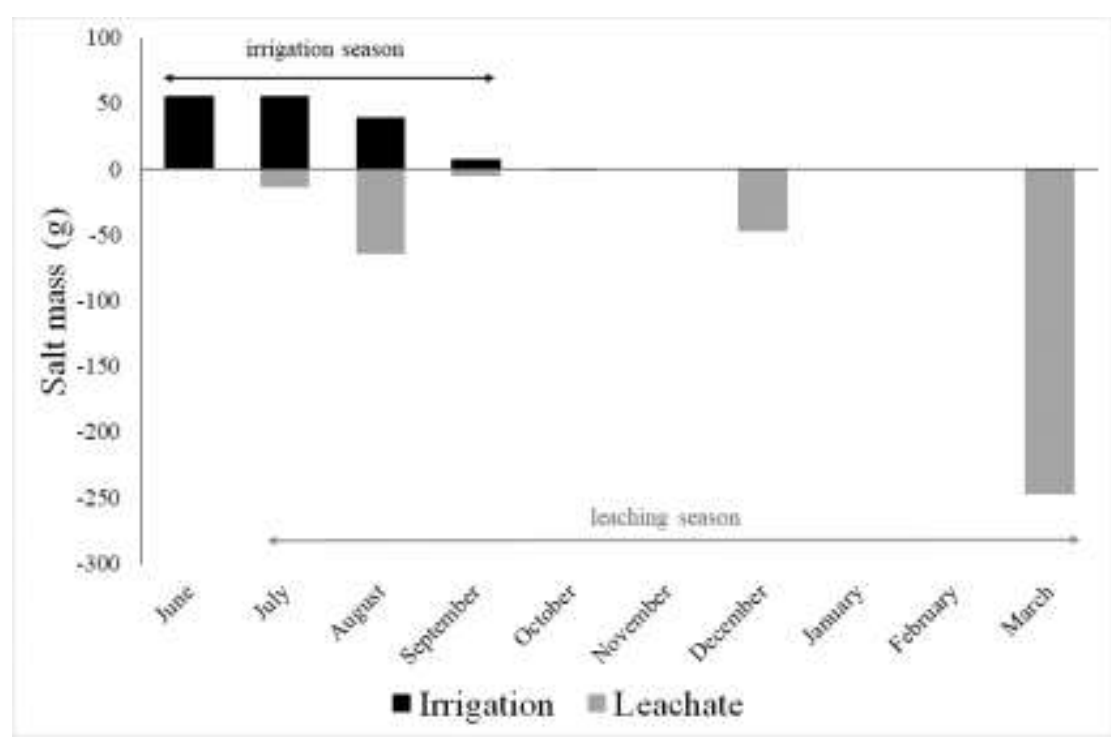

\section{Salt balance calculations}

Thayalakumaran et al. (2007) recognised that the method to calculate SB is difficult to estimate because of the mismatches of surface and subsurface hydrological boundaries, the subsoil salt store and impacts on downstream or, in this case underground water quality. Therefore, it is practical to consider SB only for the root zone. An improved understanding of the mechanism of leaching and SB can help to adapt to salt stress and to maintain plant growth and ensure successful production (Rangjian et al., 2018). By means of lysimeters, accurate data about the volumes of irrigation and drainage (leachate) can be collected precisely, hence the $\mathrm{SB}_{\mathrm{TH}}$ valid for the whole soil columns $(0-1.0 \mathrm{~m})$ can be calculated. Consequently, lysimeters are suitable to determine $\mathrm{SB}_{\mathrm{TH}}$ without taking soil samples. Nevertheless, one of the limitations of $\mathrm{SB}_{\mathrm{TH}}$ calculation is that it does not describe the absolute amount of salt or the level of average salinity in the system, just focuses only on the change in the amount of salts. Furthermore, this method cannot give any information on the stratification and translocation of salts. For field conditions, $\mathrm{SB}_{\mathrm{ACT}}$ is the suitable method providing more information though not about deep percolation.

For the better understanding of the two approaches described above, we introduce both with the data determined for the same lysimeters under study. In the investigated period, slightly negative $(-5 \mathrm{~g}) \mathrm{SB}_{\mathrm{TH}}$ was calculated meaning that salt leaching from the soil column is assumed (Table 1).

Table 1. Mean theoretical salt input, output and balance of the whole soil columns $(0-1.0 \mathrm{~m})$ in 2019

\begin{tabular}{ccc}
\hline $\mathbf{S M}_{\text {Irr }}(\mathbf{g})$ & $\mathbf{S M}_{\mathbf{L c h}}(\mathbf{g})$ & $\mathbf{S B}_{\mathbf{T H}}(\mathbf{g})$ \\
\hline 159 & -164 & -5 \\
\hline
\end{tabular}

Legends: $\mathrm{SM}_{\mathrm{Irr}}$ is the mean total dissolved salt mass in the irrigation water, $\mathrm{SM}_{\mathrm{Lch}}$ is the mean total dissolved salt mass in the leachate, $\mathrm{SB}_{\mathrm{TH}}$ is the mean theoretical salt balance

$\mathrm{SM}_{\mathrm{Irr}}, \mathrm{SM}_{\mathrm{Lch}}$ and $\mathrm{SB}_{\mathrm{TH}}$ do not give information on the TSM of the soil. If we know the initial TSM of the soil, we can estimate the final TSM on the base of the input $\left(\mathrm{SM}_{\mathrm{Irr}}\right)$ and output $\left(\mathrm{SM}_{\mathrm{Lch}}\right)$ amount of salts. The mean theoretical TSMs before (initial) and after (final) the irrigation season calculated for the soil columns of the lysimeters (0-1.0 m depth) for 2019 are illustrated in Figure 4. 


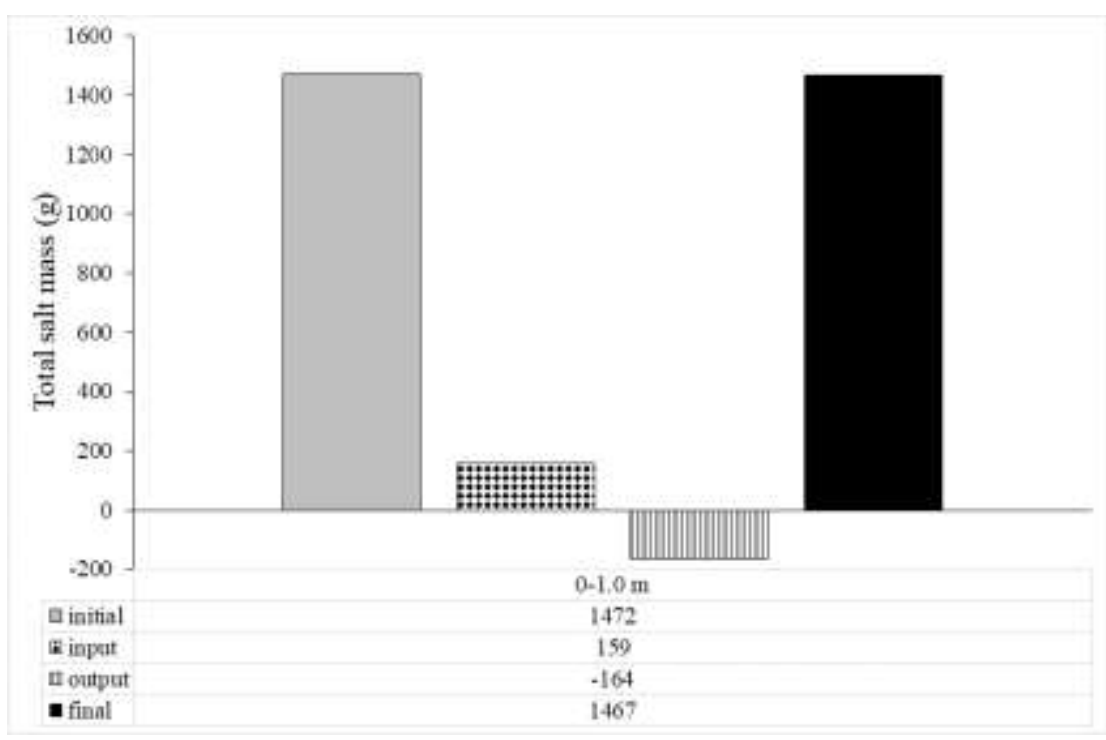

More detailed information on the process of secondary salinization can be gained by determining the salt profile of the soil column. As theoretical SM and SB calculations do not provide this possibility, the analysis of the soil samples is necessary. In our study, soil samples were taken from three soil layers $(0-0.2$,
$0.2-0.4,0.4-0.6 \mathrm{~m})$ before and after the irrigation season provided a good opportunity to determine salt profiles. Knowing $\mathrm{TSM}_{\mathrm{ini}}$ and $\mathrm{TSM}_{\text {final }}$ of the soil in the three investigated soil layers, we could determine $\mathrm{SB}_{\mathrm{ACT}}$ for each layer and consequently for the whole 0-0.6 m depth (Figure 5).

Figure 5. Mean actual salt balance of three soil layers (0-0.6 $\mathbf{m}$ depth) of the lysimeters in the irrigation season of 2019

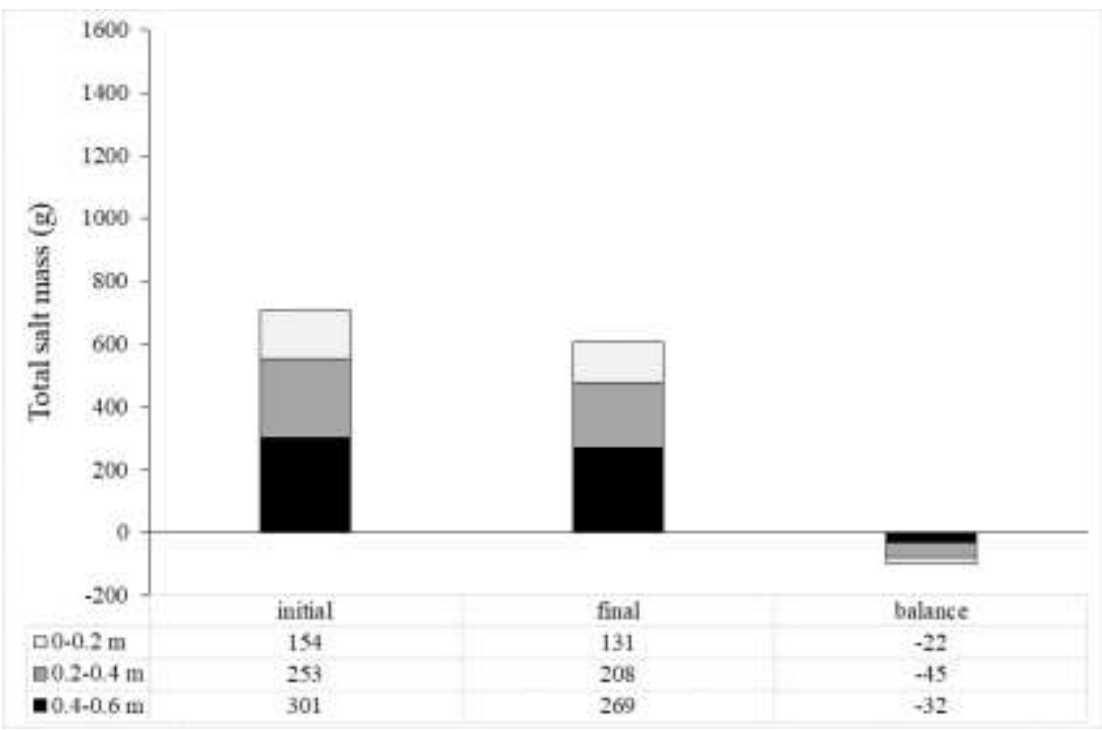

We found leaching to be the dominant process during the irrigation season as the TSM values decreased in all the three examined soil layers (negative $\mathrm{SB}_{\mathrm{ACT}}$ ). The upper $20 \mathrm{~cm}$ layer contained less salts than the lower two layers which had very similar salt contents. This result reveals that salts can and are supposed to move to the deeper layers within one irrigation period even in the case of such a heavy textured chernozem soil. The nature of this type of soils under semiarid conditions creates swelling-shrinking characteristic, which can change the distribution of pore size. The effect of the wet and dry conditions changes the distribution of moisture and solutes can be rapidly go to deeper layers or stay in upper layers causing salinization (Crescimanno and Garofale, 2006).

In our study, the determination of $\mathrm{TSM}_{\text {ini }}, \mathrm{TSM}_{\text {final }}$ and $\mathrm{SB}_{\mathrm{ACT}}$ of the soil in the three upper soil layers could 
not provide information on the salt status of the lower soil layer $(0.6-1.0 \mathrm{~m})$. Therefore, we combined the results of our $\mathrm{SB}_{\mathrm{act}}$ and $\mathrm{SB}_{\text {th }}$ calculations. This way, we determined the $\mathrm{TSM}_{\text {ini }}, \mathrm{TSM}_{\text {final }}$ and SB values for the upper and lower soil layers (Table 2).

Table 2. Mean estimated salt masses (TSM) and balances (SB) of four layers of the soil columns for the irrigation season of 2019

\begin{tabular}{lccc}
\hline Soil layer & \multicolumn{3}{c}{ Parameter } \\
& $\mathrm{TSM}_{\text {ini }},(\mathrm{g})$ & $\mathrm{TSM}_{\text {final }}(\mathrm{g})$ & $\mathrm{SB}(\mathrm{g})$ \\
\hline $0-0.2 \mathrm{~m}$ & 154 & 131 & -22 \\
$0.2-0.4 \mathrm{~m}$ & 253 & 208 & -45 \\
$0.4-0.6 \mathrm{~m}$ & 301 & 269 & -32 \\
\hline $0-0.6 \mathrm{~m}$ & 708 & 608 & -99 \\
\hline $0.6-1.0 \mathrm{~m}$ & $765 *$ & $859 * *$ & $+94 * *$ \\
\hline *actual, **theoretical
\end{tabular}

The negative SB (-99 g) of the upper $0.6 \mathrm{~m}$ of the soil column shows leaching, while the positive SB (+94 g) of the lower layer shows accumulation. Relocation of salts was taking place in the soil profile, the total amount of irrigation and the natural precipitation leached $100 \%$ equivalent of the input salts to the deeper layers and even 14\% decrease of the initial TSM of the upper layers occurred due to leaching. The TSM increase of the lower layers was $12 \%$. Traditional irrigation management, where water is not limiting, is to provide water such that the ratio of the depth of drainage to the depth of irrigation, the leaching strategy. The amount of additional water required to maintain a target salinity level, the leaching requirement (LR), is a function of crop sensitivity and irrigation water salinity (Dudley et al., 2008). Controlling or reducing salinity levels in the soil depends in the practices with water movement, which are amount of water, frequency and method of applying water, drainage and soil cultivation (Reeve and
Fireman, 1967). In accordance with other studies (Pereira et al., 2014), our preliminary lysimeter experiments also revealed that improved soil structure combined with the optimization of irrigation (control of quantity, frequency) can mitigate the harmful effects of secondary salinization (Zsembeli et al., 2019b).

\section{CONCLUSIONS}

In a lysimeter environment, the dynamics of soil moisture and salt content as well as the water- and salt balance of the soil can be precisely determined. The determination of the dynamics of the EC and the moisture content in the upper soil layer was useful to understand the salinization process in terms of the inputs of the salt balance. We found strong positive correlation between the fluctuating soil moisture content and the EC of the upper $0.1 \mathrm{~m}$ of the soil.

By calculating the theoretical and actual salt balances of the soil, we gain quantitative information on the effect of irrigation with saline on the changes of the salt content of the soil. An advantage of SBTH calculation is that it does not need soil sampling and can be done for different periods, and the leaching season can be also determined. Nevertheless, it is relevant only for the whole soil column (no salt profile data) in a lysimeter environment or areas with subsurface drainage. The advantage of SBACT is that it provides information on the relocation of salts within the soil profile, but it is limited only a certain period determined by the soil sampling dates. Combining the two calculation methods the SB of the non-sampled soil layers can be estimated. We consider our methodology adapted to lysimeter conditions suitable for deeper understanding of secondary salinization, which can contribute to mitigate its harmful effect. By repeating our measurements, we expect similar results proving that saline irrigation waters gained from the aquifers through drilled wells in Karcag are potentially suitable for irrigation if proper irrigation and soil management are applied.

\section{REFERENCES}

Ali, J.-Kapoor, S. (2008): Farmers' Perception on Risks in Fruits and Vegetables Production: An Empirical Study of Uttar Pradesh. Agricultural Economics Research Review. 28: 317-326.

Altieri, M.-Koohafkan, P. (2008): Enduring Farms: Climate Change, Smallholders and Traditional Farming Communities. Penang, Malaysia. Third World Network.

Barrios, U.-Arredondo, C.B.-Tjalling, H. (2007): Guía de manejo de nutrición vegetal de especialidad: Pimiento SQM. México, D.F. 103.

Ben-Gal, A.-Eviatar, I.-Lynn, D.-Shabtai, C.-Uri, Y.-Eugene, P.Leah, Z.-Uri, S. (2008): Effect of irrigation water salinity on transpiration and on leaching requirements: A case study for bell peppers. Agricultural Water Management. 95, Issue: 5: 587-597.

Bergstrom, L. (1990): Use of Lysimeters to estimate leaching of pesticides in agricultural soils. Environmental Pollution. 61: 325-347.
Bower, C. (1959): Chemical Amedments. Agriculture Information. United States department of agriculture. Bulletin No. 195. http://krishikosh.egranth.ac.in/bitstream/1/2031877/1/59185.pdf Search engine: Google. Key words: Soil, salinization, chemical conditioners.

Burt, C.M.-Isbell, B. (2005): Leaching of accumulated soil salinity under drip irrigation. American Society of Agricultural Engineers Vol 46 (6): 2115-2121.

Crescimanno, G.-Garofale, P. (2006): Management of irrigation with saline water in Craking Clay Soils. Soil Science of America. 1774-1787

Donatti, C.I.-Harvey, C.A.-Martinez-Rodriguez, M.-Vignola, R.Rodriguez, C.M. (2019): Vulnerability of smallholder farmers to climate change in Central America and Mexico: current knowledge and research gaps, Climate and Development,11:3, 264-286. 
Dudley, L.M.-Ben-Gal, A.-Shani. U. (2008): Influence of plant, soil and water on the leaching fraction. Soil Science Society of America, 7: 420-425.

Fida-Pnuma (2013): Smallholders, food security and the environment. Rome. FAO http://www.ifad.org/climate/resources/smallholders_report.pdf.

Hillel, D. (2005): SALINITY/Management. In: Encyclopedia of Soils in the Environment. Elsevier, pp. 435-442. https://doi.org/10.1016/B0-12-348530-4/00483-5

Kovács, Gy. (2015): Examination of carbon-dioxide emission of agricultural lands in Karcag Region. University of Debrecen. Hungary. pp. 26.

Lambert, K.-Shaiti, K. (2002): Irrigation and salinity: a perspective review of the salinity hazards of irrigation development in the arid zone. Irrigation and Drainage Systems 16: 161-174.

Martínez, G.M. (2002): El cultivo de chile guajillo con fertirrigación en el Altiplano de San Luis Potosí. Secretaría de Agricultura, Ganadería, Desarrollo Rural, Pesca y Alimentación, Instituto Nacional de Investigaciones, Forestales, Agricolas y Pecuarias. Campo Experimental Palma de la Cruz. San Luis, Potosí, México. 11.

Pereira, L.S.-Duarte, E.-Fragoso, R. (2014): Water use: Recycling and desalination for agriculture. In: Encyclopedia of Agriculture and Food Systems. Elsevier, pp. 407-424 https://doi.org/10.1016/B978-0-444-52512-3.00084-X

Rangjian, Q.-Xaiqiang, Y.-Jing, Y.-Chunwei, L.-Xiaosan, L. (2018): Effects of irrigation water salinity on growth, gas exchange parameters, and ion concentration of hot pepper palnts modified by leaching franctions. Hort Science 53 (7): 10501055.

Reeve, C.-Fireman, M. (1967): Salt Problems in Relation to Irrigation. In Irrigation of agricultural lands. Hagan, R.-Haise, H.-Edminster, T.-Diauer, C. (eds.) American Society of Agronomy. 974-984.

Rhoades, J. D.-Lesch, S.M.-Lemert, R.D.-Alves, W.J. (1997): Assessing irrigation/drainage/salinity management using spatially referenced salinity measurements. Agricultural Water Management, 35(1-2), 147-165.

Rivera, A.-Tuba, G.-Czellér, K.-Kovács, Gy.-Zsembeli, J. (2020): Mitigation of the effect of secondary salinization by micro soil conditioning. Acta Agraria Debreceniensis. 1 :115-119. DOI: https://doi.org/10.34101/actaagrar/1/3720
Sinka, L.-Rivera-Garcia, A.-Tuba, G.-Zsembeli, J. (2019): Mitigation of salt stress caused by secondary salinization. XX. Štiavnické dni 2019 - Zborník recenzovaných príspevkov 2019. 254-262.

Sharma, B.R. (1999): Regional salt and water balance modelling for sustainable irrigated agriculture. Agric. Water Manage. 40: 129234.

Thayalakumaran, T.-Bethune, M.G.-Mcmahon, T. (2007): Achieving a salt balance-Should it be a management objective? Agricultural Water Management. 92: 1-12.

Tilman, D.-Cassmank, G.-Matson, P.-Naylor, R.-Polasky, S. (2002): Agricultural sustainability and intensive production practices. Nature 418, 671-677.

Umwelt-Geräte-Technik (2020): https://www.ugt-online.de/ produkte/bodenkunde/bodenfeuchtetemperaturleitfaehigkeit/sm $\mathrm{t}-100 /$

Wang, W.-Vinocur, B.-Altman, A. (2003): Plant responses to drought, salinity and extreme temperatures: towards genetic engineering for stress tolerance. Planta, 218: 1-14.

Wilcox, L.V. (1963): Salt Balance and Leaching Requirement in Irrigated Lands. Technical Bulletin No. 1290.

Zsembeli, J.-Kovács, Gy.-Szúcs, L.-Tóth, J. (2013). Examination of secondary salinization in simple drainage lysimeters. Gumpensteiner Lysimetertagung. 153-156.

Zsembeli, J.-Szücs, L.-Blaskó, L. (2011): Secondary salinization by irrigation from drilled wells in Karcag area. $10^{\text {th }}$ Alps-Adria Scientific Workshop.

Zsembeli, J.-Czellér, K.-Sinka, L.-Kovács, Gy.-Tuba, G. (2019a): Application of lysimeters in agricultural water management; In: Máchal, Pavel (szerk.) Creating a platform to address the techniques used in creation and protection of environment and in economic management of water in the soil. Brno, Csehország: International Visegrad Fund, pp. 5-21.

Zsembeli, J.-Sinka, L.-Rivera-García, A.-Czellér, K.-Tuba, G.Koloman, K.-Findura, P. (2019b): Effect of Soil Conditioning on the Moisture Content and the Salt Profile of the Soil Under Irrigation with Saline Water, Agriculture (Pol'nohospodárstvo), 65(2), 77-87. doi: https://doi.org/10.2478/agri-2019-0008 